\title{
Welfare Reform at 15 and the State of Policy Analysis
}

\author{
Stephen Pimpare
}

\begin{abstract}
This article offers a review of welfare reform evaluation studies, summarizing research that has generated a consensus among mainstream policy analysts that the Personal Responsibility and Work Opportunity Reconciliation Act of 1996 (PRWORA) has had few effects beyond caseload reductions and increases in employment. Given that supporters and opponents alike expected the law to have profound consequences, the article considers two ways to explain this surprising outcome, showing that (1) quantitative policy analysis has been ill equipped to capture the PRWORA's effects and (2) expectations were nonetheless wrong because they failed to appreciate how thoroughly Aid to Families with Dependent Children had already been eroded in the decades prior to its reform. Welfare reform was not the beginning of a process of policy change; it was the end of one. In response to these findings, the article describes how a more critical perspective on reform matters for social work researchers, advocates, and practitioners.
\end{abstract}

KEY WORDS: insecurity; policy analysis; policy practice; poverty; welfare reform

$\mathrm{T}$ he Personal Responsibility and Work Opportunity Reconciliation Act of 1996 (PRWORA) (P.L. 104-193) marked its 15th anniversary on August 22, 2011. Although amendments to the Social Security Act of 1935 (P.L. 74-271) had altered Title IV-A, Aid to Dependent Children (ADC), with some frequency, the PRWORA was arguably the most substantial reconfiguration of American poor relief since the New Deal. Opponents of the law offered dire warnings as it moved toward enactment: One study commissioned by the U.S. Department of Health and Human Services (HHS) estimated that more than 1 million children would be made newly poor (Edelman, 1997), leading New York Senator Daniel Patrick Moynihan (1996) to call it "the most regressive and brutal act of social policy since Reconstruction” (p. 8076). Proponents, by contrast, predicted that the PRWORA would reduce out-of-wedlock births, increase marriage rates, improve poor women's labor force participation rates, and, as a result of these factors, improve the material and moral well-being of "dependent" families.

Curiously, it remains unclear which side was right. Comprehensive policy evaluation is always difficult: Policy goals can be conflicting or ambiguous, determining causality remains an imperfect science, policies may have diffuse impacts that are impossible to fully trace, and accurate, consistent, and comprehensive data may be unavailable or hard to acquire. But the evaluation challenge posed by the PRWORA seems to be greater than that which normally prevails.

First, although it has been common to speak of "welfare reform" in the singular, the PRWORA established a national framework within which states were expected to innovate to suit their own preferences, and their implementing legislation has varied along multiple dimensions, including thresholds for determining eligibility; benefit amounts; categories of eligible individuals; time limit policies; work requirements (including the definition of work itself); the availability and generosity of child care subsidies; sanction policies; the use and content of diversion programs or payments to discourage applications; whether families are required to meet school attendance, immunization, drug testing, or health screening requirements; which policies and programs are carried out by public agencies and which are contracted or subcontracted to for-profit or not-for-profit organizations (and how adequately they are funded and monitored and the manner in which their incentives are structured); and the extent to which street-level implementation reflects the law as written (Urban Institute, 1997-2008).

Further complicating evaluation, these policies, their funding, and the manner in which they 
were implemented vary within states from county to county and even city to city. As a consequence, there are many more than merely 50 configurations or "bundles" of policy reforms, and each was carried into effect in locations that differed in their unemployment rates, prevailing wages, and opportunities available to the lower-skilled and less-educated women who are the typical beneficiaries of welfare. Although there was variation across states under ADC and its successor, Aid to Families with Dependent Children (AFDC), regarding eligibility rules and benefit levels, states were otherwise constrained by national standards. One way we can productively alter our thinking about PRWORA is to take more seriously the fact that there has been no such thing as welfare reform: There has, instead, been a multiverse of welfare reforms, with variation far surpassing that which is regularly produced by American-style federalism.

Isolating and gauging the effects of PRWORA have been additionally bedeviled by economic circumstances. Most reforms went into effect during the boom of the late 1990s, a period of rapid growth and job creation, rising wages, and low unemployment during which the Earned Income Tax Credit (EITC) underwent a large expansion and supplemented the income of the very population most affected by PRWORA, making it difficult to isolate the effects of PRWORA during these years (Blank, 2007). More recently, reforms have been put to another test as the economy suffered its worst decline since the Great Depression. Though in some ways PRWORA was an ideal natural experiment, with hundreds (if not thousands) of new approaches to poor relief unfolding during a period of anomalous boom followed by a historically deep and broad trough, such conditions have taxed our abilities to isolate program effects and to account for variation across time, space, and program configuration. To make matters worse, because by 1996 there were 43 states already operating their AFDC program under waivers granted by HHS that allowed them to undertake their own welfare "experiments," not even the timing of reforms is consistent (Grogger \& Karoly, 2005; Ziliak, 2009).

Finally, the ability to gauge outcomes is hobbled by the lack of consensus among researchers on how to define success and, as a result, which indicators are most salient (Cancian \& Meyer, 2004), a problem rooted partly in the failure of PRWORA to include standards or funding for its evaluation (the closest the law came was a set of general goals: to reduce welfare receipt and out-of-wedlock pregnancies while "promoting" work and marriage; \$401). Variation is thereby multiplied across even more dimensions as different analysts identify differing dependent variables. It is only a slight exaggeration to say that each analysis of welfare reform has, for all intents and purposes, examined a different program.

\section{FINDINGS OF QUANTITATIVE POSTREFORM EVALUATION RESEARCH}

Evaluation studies have nevertheless not lacked in quantity, variety, or sophistication, and because of their abundance we have a growing corpus of literature reviews and meta-analyses as well (Acs \& Loprest, 2007; Besharov, Germanis, \& Rossi, 1997; Blank, 2002, 2007; Greenberg, Cebulla, \& Bouchet, 2005; Grogger \& Karoly, 2005; Grogger, Karoly, \& Klerman, 2002; Lichter \& Jayakody, 2002; Michalopoulos, 2004; Ziliak, 2009). Yet for all this diversity and rigor, the most succinct answer to the question of what we know about the effects of PRWORA seems to be this: very little. There is agreement among researchers that welfare reforms contributed to historic declines in the rolls and, at least for a time, increases in poor women's workforce participation rates (with disagreement about the scale of those contributions). Beyond that, there is little consistent evidence of strong and significant effects, and the net impact appears to have been modest. At the same time, because of the wealth of research and the range of its findings, one can identify an evaluation study to support almost any claim (supporters and opponents alike have been guilty on this count). Meta-analyses that seek cumulative evidence or enduring patterns are therefore especially useful.

Although not the only early overview (see also Blank, 2002), the consensus is encapsulated in a 2002 meta-analysis by the RAND Corporation (Grogger et al., 2002) that reviewed 34 experimental (random assignment) studies and 33 observational (econometric or regression) analyses. The report's summary chart (Table S.2) contained, by my count, 242 cells identifying the effects of 11 policies or policy bundles across 22 
outcome measures. It found "much evidence" to support only 11 causal relationships: Mandatory work-related activities had no demonstrable effects on (1) marriage and (2) fertility rates, and their effect on (3) income was mixed. Work requirements otherwise decreased (4) welfare and (5) food stamp use, increased (6) employment and (7) earnings, and negatively affected (8) school achievement among adolescents. Cash bonuses that were linked to the number of hours women worked increased their (9) employment, (10) earnings, and (11) total income. There was no strong evidence-though there was, on occasion, weak evidence-for any effects from the family cap (which denied benefits to children born while their mother was on the rolls), time limits, or sanctions (with the exception of some hint that sanctions decreased welfare use). There was some evidence for effects of various other program policies, notably on welfare use and employment (although here, again, some of the evidence was mixed rather than all pointing in the same direction), but there was little or no reliable evidence of relationships between welfare policies and outcomes for fully 204 of the cells in the matrix, or 84 percent of the relationships under consideration (there was no reliable evidence at all for just under half).

This surprising pattern would hold: Evidence accumulated that PRWORA decreased welfare use, increased employment rates, and had no effects on marriage or reproduction, whereas its effects on the well-being of poor women and their children would remain largely unexamined, undetected, or unquantified. In later work, Grogger and Karoly (2005) undertook another meta-analysis, this time of 59 studies, and once again, work requirements, the most studied provision of PRWORA, showed a negative impact on welfare use and a positive impact on employment and earnings from wages. The impact of work requirements on total income and on poverty rates remained unclear-findings were mixed or, especially as related to poverty, not significantand research continued to be unable to isolate the consequences of time limits and sanctions. There was only one study that found any significant relationship between any reform policy and marriage or childbearing rates (and even insignificant findings were roughly divided between those that found positive and negative effects).
Similarly, studies examining child well-being were about as likely to find that work requirements helped as harmed children, whereas the research on most other policies remained too scant to conclude much of anything. As Grogger and Karoly characterized the 132 cells of this updated matrix, "61 are empty, and another 12 contain only insignificant results. Many of the remaining cells contain a single significant result" (p. 248).

Blank's (2007) less methodologically formal review of the then-recent evaluation literature likewise found strong evidence that welfare reforms contributed significantly to large caseload declines and to (much smaller) increases in women's employment (although the expansion of EITC and the strong economy were as important as or more important than PRWORA) but that it remained difficult to identify "overall policy lessons." Reforms may have led to reductions in health insurance coverage, but with few apparent short-term effects on healthy behavior or health outcomes. The new policies had seemingly limited effects on child health or well-being but significant positive effects on the availability of child care. PRWORA had no discernible effect on marriage and, at best, very minor effects on fertility, whereas it caused predictable changes in consumption patterns, as more was spent on transportation, clothing, and meals eaten out of the home. It may have contributed to declines in food stamp and Supplemental Security Income (SSI) use (presumably because eligibility rates declined as income from wages rose among the research subjects) and seems to have had little or no effect on savings rates among poor households. Acs and Loprest (2007) came to similarly mixed and modest conclusions in that same year, as did Ziliak (2009) soon thereafter.

\section{SOLVING BLANK'S CONUNDRUM}

This vast body of state-of-the-art social science research presents a conundrum, according to Blank, a prominent policy analyst and former director of the University of Michigan National Poverty Center who since June 2012 has served as acting secretary of the U.S. Commerce Department:

It is striking how many questions about the effects of this policy change remain unanswered.... The movement off public assistance 
and into work was far greater than I would have guessed possible in such a short period of time ... [but] given that such dramatic changes did occur, I am surprised at how little [that movement has] affected other domains of life for these women. (Blank, 2007, pp. 2, 31-32)

There are two ways to approach solving this apparent puzzle. First, it is possible that the research is right but supporters' and opponents' expectations of large-scale change were wrong: Welfare reform really has had only modest effects beyond caseload reductions. Alternatively, it could be that the predictions were accurate and there have been other large, significant effects, but the research Blank and her peers have relied on has been unable to capture them. Let us turn first to the latter possibility, given how important it is for social workers who work with and fight for poor families to have accurate information about the effectiveness of welfare programs and policies: Has evaluation research failed us?

\section{Limitations of Mainstream Policy Analysis}

We have sophisticated tools available for evaluating the effects of welfare reforms (for example, Fang \& Keane, 2004), but they are telling us little. This is a consequence of the complexity of the policies being enacted, their variation over time and place, and the scarcity of reliable and consistent data, to be sure, and the systematic evaluation of PRWORA was always destined to be a challenge, as suggested earlier. But because the policy sciences have come to rely on too narrow a range of techniques, which are especially ill suited to understanding the tumultuous and interdependent lives of poor women with children, the results have been more confounding than even a pessimist might have predicted. Let me highlight a few of the problems.

Most evaluations report average effects, which in this case obscures the fact that different reforms or bundles of reform may affect different categories of poor women in different ways. Some programs or program bundles may be effective for some subpopulations but ineffective for others, distinctions potentially lost depending on the methodology used and the researcher's sensitivity to such variation and complexity. Precisely because the impacts can be so disparate, however, this is a crucial flaw: Ziliak (2009), in this vein, posited that PRWORA might be considered a success if we examine outcomes on better-educated women with younger children but a failure if we look at their counterparts with less education and teenagers at home. Yet even this distinction highlights the problem, given that there seem to be nontrivial numbers of women in the first category also faring poorly, and there are no satisfactory answers as to why these particular differences should be. More important, such judgments are made on the basis of estimates of changes to household income, but such households are not necessarily better off, depending on what tradeoffs they have made or new expenses they have incurred.

A related problem is that research has tended toward snapshot and short-term analyses that seldom capture the dynamism of the rolls or the volatility of poor people's economic lives, thereby risking understating the decline in quality of life in poor households (Heflin, 2006). Similarly, analyses seldom offer comparison data from before the implementation of Temporary Assistance to Needy Families (TANF) in 1997 that help us evaluate the meaning of their findings (but see Bitler, Gelbach, \& Hoynes, 2006; Cancian, Haveman, Meyer, \& Wolfe, 2002; Fang \& Keane, 2004). Moreover, short-term studies (and most analyses have focused on a time frame of at most two years) cannot uncover evidence for effects that may unfold over the long term, such as changes in health outcomes or in marriage rates and reproductive choices (Blank, 2007; Grogger \& Karoly, 2005), nor can most capture nominally small (but proportionately large) fluctuations in a poor household's income. To illustrate my point: some research shows that families receiving benefits from the Supplemental Nutrition Assistance Program (SNAP, formerly food stamps) are still "food insecure" but 30 percent less so than they would be otherwise (Ratcliffe \& McKernan, 2010), yet other research has concluded that SNAP participation does not reduce food insecurity (Huffman \& Jensen, 2008). We can explain this if SNAP does reduce hunger but not dramatically enough for it to consistently register in our data. This may likewise be the case with cash welfare. 
Furthermore, TANF studies have generally examined only a few variables at a time, limiting opportunities to capture interaction effects or, indeed, much of the complexity of policies and poor people's lives. The dilemma is that the most convincing and methodologically sound analyses are precisely those most narrowly focused on the effects of discrete program elements on a distinct population (Blank, 2007). Rarely have evaluations been able to disentangle effects of various reform components - time limits, sanctions, the family cap, tax incentives - from the effects of an amorphous policy called "welfare reform" (Grogger \& Karoly, 2005). Furthermore, they may not be able to separate out large economic effects for any of them: Some of the research summarized previously ends before the recession of 2001, and none of it captures the Great Recession of 2007 to 2009. Perhaps once the macroeconomic noise has subsided, patterns of change related to TANF policies will be easier to discern (but see Bitler \& Hoynes, 2010), for even though there was some research consensus on postreform changes in employment, by the early 2000 s those trends were in retreat.

Average effects obscure other kinds of variation, and we should note the paucity of research on how outcomes vary by race, although there are indications that African Americans have fared worse (Cherlin, Frogner, Ribar, \& Moffitt, 2009). The size of a state's African American population has been found to be a predictor of whether a state would adopt restrictive TANF policies, and race was a factor in imposing shorter time limits and including a family cap provision (Soss, Schram, Vartanian, \& O’Brien, 2001). Racial biases may also be affecting the implementation of TANF polices in welfare offices, an outcome of particular import to the social work profession (Fording, Soss, \& Schram, 2011; Watkins-Hayes, 2009).

Ironically, for all their attention to work, evaluation studies have paid little attention to the labor market effects of reform (Grogger \& Karoly, 2005, Figure 10.1) or undertaken attempts to situate relief withdrawal with broader developments in the U.S. and global political economy. There are exceptions. Soss et al. (2001) found a positive relationship between tough work-first TANF policies and high incarceration at the state level, offering suggestive evidence for longstanding claims by Piven and Cloward (1971) that welfare programs function to discipline potentially unruly populations and to regulate labor supply. Soss et al. also found a significant relationship between a state's unemployment rate and its likelihood of adopting stricter rules under its TANF program: States with tighter labor markets adopted stricter work policies (forcing more people into the low-wage labor market and thereby reducing wages). More recently, Piven (2006) saw overall government efforts at social policy reform as simultaneously following contractionary and expansionary tracks, as decommodifying programs (that is, those that enable survival apart from the labor market) are reined in (as with AFDC) and commodifying programs (that is, those that enforce work) are expanded (for example, EITC). This claim highlights what can be lost by the restrictive purview of much research: Analysts have focused almost exclusively on the contractionary narrative (with AFDC and TANF at the center) while ignoring the fact that other portions of the welfare state have expanded (including the most repressive institutions of the criminal justice system). It is similarly notable that analyses rarely use the decommodification metric referenced earlier despite the fact that it has dominated comparative welfare state analysis for two decades (Esping-Andersen, 1990). In this way, not only has U.S. research on welfare and the welfare state isolated itself from the scholarly questions that have helped define the discipline for the rest of the Western world, but it has failed to attend to the range of policy changes that are likely having an impact on poor American families, in turn hampering social work advocates' ability to make sound decisions about where to target their efforts.

More curious (and perhaps surprising), although research has determined that welfare reform reduced the number of women receiving assistance and pushed many into work, analysis of how this has affected their well-being remains scarce, in part because poverty has been among the least-studied outcomes (Grogger \& Karoly, 2005). Analysts have, even if unwittingly, allowed antiwelfare reformers to frame their research agenda, emphasizing caseloads and work effort at the expense of other indicators. To the extent that social work researchers have been complicit, this is another indication of how a more critical appraisal can lead us toward better policy analysis and then better policy interventions. 


\section{Insights from Ethnography}

As we have seen, the analysis by economists, political scientists, and some social workers and sociologists that has dominated in policy research organizations, in government agencies, and among policy scholars has uncovered limited evidence of significant and sizable effects of PRWORA beyond caseload declines and short-term employment and wage increases. However, if we turn our attention to the work of anthropologists, journalists, and other social workers and sociologists, evidence of significant change becomes apparent as we hone in on the lived experience of poor families (Anderson, Halter, \& Gryzlak, 2004; Collins \& Mayer, 2010; DeParle, 2004; Hays, 2003; Henrici, 2006; Morgen, Acker, \& Weigt, 2010; Morgen \& Maskovsky, 2003; Seccombe, 2010; Watkins-Hayes, 2009; Zedlewski \& Golden, 2010).

Under TANF, bouts of economic insecurity and household instability appear with much more frequency than was the case under AFDC. Indeed, while insecurity has increased across the population, it has been more acute among poorer Americans (Hacker, Rehm, \& Schlesinger, 2010, Figure 8). When employed, many poor women do earn more than they would have from welfare, but a relief check is reliable, whereas work is not, in part because the exigencies of their lives make it exceedingly difficult to retain a job. We can see how analyses would show increases in household income over the near term as women entered the labor market, but over time they may be left with less income than if they had remained on welfare. Many women report running out of food more frequently and missing bill payments more often. Another kind of insecurity faces their children, and although changes in health, mental health, school achievement, and criminal activity have not consistently appeared in quantitative analyses, there are clear indications of problems in this other strain of research. It is suggestive (although no more than that so far), moreover, that although relief rolls have been declining (until quite recently), there were increases in homelessness, requests for emergency food, and applications for food stamps even before the Great Recession (U.S. Department of Agriculture, 1995-2008; U.S. Department of Housing and Urban Development, 2007-2010).

We know that poor women are more likely to suffer from mental illness, to have physical disabilities, or to be caring for a sick or disabled child; the lives of these women have been made much worse, it seems. Anxiety, fear, depression, and anger appear to have been exacerbated. Taken together, these studies reveal the "varieties of little-noticed suffering," in Neubeck's (2006, p. 67) apt phrase. They do not offer us scientific surety, telling us with precision how many women are doing worse, or exactly how much worse. But neither do the studies that aspire to such quantification, as we've seen. While there is truth to the adage that the plural of anecdote is not data, this growing body of ethnographic research offers troubling indicators that welfare reform has harmed poor families, suggesting that we should treat with caution the claim that there have been modest or minimal effects as a result of PRWORA. At the same time, the evidence available does not justify indictment of PRWORA as a profound failure, either.

\section{Errors of Expectation and the Prereform Erosion of Relief}

The previous discussion outlines one kind of explanation for Blank's conundrum: Reform has been too varied and complex to be captured by the tools that dominate policy research (and public policymaking), although there is other evidence that important changes have been occurring in poor households. That said, it may nevertheless not be that effects are large and research is failing to capture them, but that effects truly are small and expectations should have been more modest. After all, although it was part of many poor mothers' strategy for getting through the month, AFDC was always a relatively modest portion of household income because its benefits were always meager: Never in the history of AFDC in any state were its benefits, even when combined with the value of food stamps, enough to lift a family above the poverty line (U.S. House of Representatives, 2006).

As a consequence, households that received income from welfare had to supplement it with income from multiple other sources. Edin and Lein (1997) documented this in their extended study of the survival strategies of welfare-reliant households in the pre-TANF era: Poor mothers survived (then as now) thanks to help from family, friends, neighbors, and partners; income (legal and illegal) from other members of the 
household; irregular bouts of unreported income from low-wage labor in the formal economy; work in the informal economy; income from other government programs; the bartering of services and goods; and pawn shops, loan sharks, payday loan brokers, or credit accounts with local merchants. In Edin and Lein's sample of AFDC households, that program provided, on average, 35 percent of monthly income. We cannot and should not dismiss the importance of that money, especially for those households above the mean, but it was a minority share of their total (it would have to be, given benefit levels). And AFDC was even less important in states with lower benefits: In 1996, the maximum monthly benefit for a Mississippi family of three was $\$ 120$ (Gabe, 2008).

Nationally, the average monthly benefit in 1996 was $\$ 371$ per family, with 4.5 million families on the rolls. Before reform, welfare lifted 1 percent of poor people above the poverty line; by contrast, the figures were 5 percent for SNAP and 10 percent for the EITC (HHS, 1997; Meyer, 2009). By 2006, with an average monthly benefit of $\$ 372$ per family (in nominal dollars) and 1.8 million families on the rolls, TANF reduced poverty by 0.6 percentage points; the comparable figures were 2 to 3 points for SNAP and 5 for the EITC and the Child Tax Credit. That's a decline of 40 percent but amounts to less than one half of one percentage point. And in both periods TANF was less important than other programs (which saw comparable declines in their effectiveness). As Gabe (2008) observed for the Congressional Research Service, "cash welfare benefits have little impact on the poverty rate" (p. 16).

By 2006, the median maximum monthly cash benefit for a family of three equaled 29 percent of the poverty line, compared with 35 percent in 1996 and 52 percent in 1981 (U.S. House of Representatives, 2008, Tables 7-21, 7-22). It is worse under TANF-benefits are lower and reach fewer people-but the relevant point is that the decline long preceded PRWORA: The real average value of maximum AFDC benefits had already fallen 51 percent between 1970 and 1996 (U.S. House of Representatives, 1996, p. 442). Moreover, to focus solely on AFDC and TANF is to miss the larger story of trends in U.S. social policy: Welfare benefits reached their peak value in 1968, the same year the minimum wage hit its peak; unemployment insurance benefits reached their peak in 1972, food stamps in 1981, and disability insurance in 1982 (although the EITC reached its peak in 2000) (Mettler \& Milstein, 2007).

Had AFDC played a more central role in the economic lives of poor women, we might expect more dramatic effects to have appeared in the data when former recipients were cut off. Fears that PRWORA would cause massive disruption in the lives of poor single-parent families were thus overblown: Because the value and reach of AFDC had already been so thoroughly eroded by 1996 , welfare reform's direst effects have been contained to a subset of the most desperate and vulnerable Americans. The harm caused by PRWORA has been real, but damage has not been widespreadmaking it invisible to many analysts and their tools of evaluation-because welfare use was not widespread. Scholars had been writing about the declining value of AFDC for years prior to 1996, but the implications of that were not taken seriously enough in predictions about the effects of PRWORA. That it was such a widespread misdiagnosis suggests that social policy analysis needs to more consistently attend to incremental change and that efforts by social workers to defend AFDC came much too late.

We are accustomed to expecting policy change to emerge from high-profile battles over the enactment or, in this instance, the repeal of landmark legislation-the Social Security Act, Medicare, or the Patient Protection and Affordable Care Act. But change can also come incrementally, and entirely new policy regimes can quietly come into being over long periods of expansionary feedback and drift (Hacker \& Pierson, 2010; Pierson, 2004). AFDC had undergone such change well before PRWORA (and had never been the central source of support for poor households), but because AFDC had been so successfully wielded as a political weapon to such remarkable effect, there has been misapprehension of the true nature of the program and the role it has played in the lives of poor mothers. The effects of PRWORA have been hard to see because the benefits of the welfare programs it targeted had already been quietly whittled away. Its enactment in this way was more the end stage of a process of policy change than it was the beginning of one, and the widespread surprise over the limited evidence of TANF's impact may be because debate about PRWORA was so charged: 
Proponents and opponents were all deeply invested in its success or failure and used rhetoric that prophesied transformative success or catastrophic failure, with little demand for more circumspect projections.

\section{CONCLUSION}

The diverse reforms enacted thanks to PRWORA reduced welfare receipt, as intended, and half of those who are eligible for assistance are now on the rolls (Rosenberg et al., 2008). Such declines are a relevant indicator of PRWORA's effects, but a narrow one: It is not obvious that a reduction in enrollments per se is an outcome deserving of approbation. The logic of these reforms dictates that work is always better than nonwork (at least for poor women), that welfare receipt is always the least desirable option, and that poor women are unable to make sound decisions regarding marriage and childbearing without state intervention. These are contestable claims, but they are the assumptions undergirding PRWORA. There is a related bias in much of the mainstream TANF analysis, captured succinctly when, tempering his estimation that on balance research points to a small negative net outcome, Ziliak (2009, p. 17) wrote, "On the plus side, long-term dependence on welfare has been cut substantially, if not altogether eliminated for a majority of recipients, and the number of new recipients has been slashed." Beyond the fact that reducing the rolls was a goal of PRWORA (and setting aside debates about whether long-term use was in fact the experience of most AFDC recipients), why should such declines be counted "on the plus side" absent an evaluation of those women's wellbeing? Ziliak simultaneously adopted an uncritical usage of dependence that ignores a large body of feminist scholarship going back, at least, to Fraser and Gordon's (1994) “A Genealogy of Dependency."

The failure to comprehend the material circumstances, the lived experiences, and the actual, rather than imagined, constraints and opportunities in poor households has contributed to the murky conclusions of policy analyses and their inability to discern the effects of PRWORA, drawing renewed attention to what can be missed by the scholarly fetishization of quantitative methods (Pierson, 2007) and, as with Ziliak (2009), highlighting the biases of "objective" policy research.
Ethnography has its limits, too (Wedeen, 2010), but it may be that there is a need to eschew an impulse to identify generalizable patterns and quantifiable outcomes and accept that welfare repeals are unfolding in very different ways depending on the particular programmatic configuration of policies in various states and localities and local economic and labor market conditions. What has been found in ethnographic studies of poor women and their households is that their lives, always difficult, have been made differently difficult - better for some, worse for others, mostly still awful, but differently awful. Those differences can be described, but it may be that they cannot be quantified. This observation can serve as another reminder of how important it is for case workers to comprehend the particular challenges facing each family before them, to resist assumptions about what causes women to turn to public assistance, and simultaneously to resist the impulse to offer each the same solution. Although this may seem obvious in the abstract, ample research demonstrates that it often fails in practice (see, for example, Fording et al., 2011; Hays, 2003; Watkins-Hayes, 2009).

The failure to better explore the relationship between TANF and other sources of income in poor households is another problem: If welfare reform can be understood as one instantiation of a new political economy of neoliberal retrenchment or of globalization, as some scholars have argued (Collins \& Mayer, 2010; Piven, 2006), then narrow, isolated, econometric analyses of TANF data alone have little chance of shedding light on the processes at work or on the ways macro-level activities affect the individual or the household at the micro level. To focus so relentlessly on TANF in isolation is like a physician attempting to diagnose a patient while refusing to examine more than her or his blood pressure.

In 2009, 32 percent of food pantry clients reported that their primary source of income was employment; for 23 percent, it was social security; for 10 percent, it was Social Security Disability Insurance (SSDI) or workers' compensation. For only 1.3 percent, TANF was their principal support (Mabli, Cohen, Potter, \& Zhao, 2010). Only 5 percent of the households surveyed reported any income from TANF, whereas over 6 percent received income from their local General Assistance Program. Higher percentages received 
income from work (38 percent), social security (33 percent), unemployment insurance ( 8 percent), SSDI or workers' compensation (17 percent), SSI (19 percent), relatives (11 percent), pensions (8 percent), or child support (6 percent). The only income sources on which fewer clients relied than TANF were alimony (0.4 percent) and child care subsidies (2.3 percent) (Mabli et al., 2010). For the 593,900 food pantry clients who received income from TANF (and the 65,200 soup kitchen patrons and 48,700 shelter residents), these funds were, perhaps quite literally, vital. But they were utterly immaterial for the other 36 million who were nonetheless poor enough to seek emergency food. It is fitting and proper that research, advocacy, and casework be devoted to TANF, but the attention to the program has been out of proportion to its usefulness to poor families, and, as a consequence, scarce resources of time, energy, attention, and money have been misallocated.

For most poor families, the program that has been transformed from ADC to AFDC to TANF is now irrelevant, for rather than "ending welfare as we know it," we have, for all but a few, ended welfare. In its place is a more complex array of supports on which they must rely. Evaluation studies have not ignored these other sources, but given the transformation, it is time to shift the emphasis from measuring the effects of TANF and other individual programs to developing data and tools for evaluating the well-being of families, looking for patterns in where their income comes from, how income sources change over time, and how these changes affect their household. Since the passage of welfare reform, the safety net has become less effective at lifting people out of poverty; it has become even less effective at lifting children out of poverty and at lifting children out of deep poverty (Sherman, 2009). TANF, however, represents only a portion of this failure, and short of significant (and unlikely) changes to PRWORA or to state-level implementing legislation, its impact will remain marginal, given its narrow reach. As a result, analyses that focus on TANF will continue to be unable to shed much light on poor families, and social work advocates who focus too narrowly on welfare risk failing to attend to other programs that may have a greater impact on poor households. The symbolic power of the old welfare program remains, but it now matters too little for it to receive such a disproportionate share of analysis. It is time for us to end welfare scholarship as we know it. SW

\section{REFERENCES}

Acs, G., \& Loprest, P. (2007). Final report: TANF caseload composition and leavers synthesis report. Washington, DC: Urban Institute.

Anderson, S. G., Halter, A. P., \& Gryzlak, B. M. (2004). Difficulties after leaving TANF: Inner-city women talk about reasons for return to welfare. Social Work, 49, 185-194.

Besharov, D., Germanis, P., \& Rossi, P. H. (1997). Evaluating welfare reform: A guide for scholars and practitioners. College Park: University of Maryland School of Public Affairs.

Bitler, M. P., Gelbach, J. B., \& Hoynes, H. W. (2006). What mean impacts miss: Distributional effects of welfare reform experiments. American Economic Review, 96, 988-1012.

Bitler, M. P., \& Hoynes, H. W. (2010). The state of the safety net in the post-welfare reform era (Working Paper 2010-31). San Francisco: Federal Reserve Bank of San Francisco.

Blank, R. M. (2002). Evaluating welfare reform in the United States. Journal of Economic Literature, 40, 1105-1166.

Blank, R. M. (2007). What we know, what we don't know, and what we need to know about welfare reform (Working Paper 07-19). Ann Arbor, MI: National Poverty Center.

Cancian, M., Haveman, R., Meyer, D. R., \& Wolfe, B. (2002). Before and after TANF: The economic wellbeing of women leaving welfare. Social Service Review, 76, 603-641.

Cancian, M., \& Meyer, D. R. (2004). Alternative measures of economic success among TANF participants: Avoiding hardship, poverty, and dependence on public assistance. Journal of Policy Analysis \& Management, 23, 531-548.

Cherlin, A., Frogner, B., Ribar, D., \& Moffitt, R. (2009). Welfare reform in the mid-2000s: How African American and Hispanic families in three cities are faring. Annals of the American Academy of Political and Social Science, 621, 178-201.

Collins, J. L., \& Mayer, V. (2010). Both hands tied: Welfare reform and the race to the bottom of the low-wage labor market. Chicago: University of Chicago Press.

DeParle, J. (2004). American dream: Three women, ten kids, and a nation's drive to end welfare. New York: Penguin Books.

Edelman, P. (1997). The worst thing Bill Clinton has done. Atlantic, 297(3), 43-58.

Edin, K., \& Lein, L. (1997). Making ends meet: How lowincome mothers survive welfare and low-wage work. New York: Russell Sage Foundation.

Esping-Andersen, G. (1990). The three worlds of welfare capitalism. Princeton, NJ: Princeton University Press.

Fang, H., \& Keane, M. P. (2004). Assessing the impact of welfare reform on single mothers. Brookings Papers on Economic Activity, 1, 1-95.

Fording, R., Soss, J., \& Schram, S. (2011). Race and the local politics of punishment in the new world of welfare. American Journal of Sociology, 116, 1610-1657.

Fraser, N., \& Gordon, L. (1994). A genealogy of dependency: Tracing a keyword of the U.S. welfare state. Signs, 19, 309-336.

Gabe, T. (2008). Trends in welfare, work, and the economic well-being of female-headed families with children, 19872006. Washington, DC: Congressional Research Service. 
Greenberg, D., Cebulla, A., \& Bouchet, S. (2005). Report on a meta-analysis of welfare-to-work programs (Discussion Paper No. 1312-05). Madison, WI: Institute for Research on Poverty.

Grogger, J., \& Karoly, L. (Eds.). (2005). Welfare reform: Effects of a decade of change (Figure 10.1). Cambridge, MA: Harvard University Press.

Grogger, J., Karoly, L., \& Klerman, J. (2002). Consequences of welfare reform: A research synthesis. Santa Monica, CA: RAND Corporation.

Hacker, J. S., \& Pierson, P. (2010). Winner-take-all politics: How Washington made the rich richer-and turned its back on the middle class. New York: Simon \& Schuster.

Hacker, J. S., Rehm, P., \& Schlesinger, M. (2010). Standing on shaky ground: Americans' experiences with economic insecurity. New York: Rockefeller Foundation.

Hays, S. (2003). Flat broke with children: Women in the age of welfare reform. New York: Oxford University Press.

Heflin, C. M. (2006). Dynamics of material hardship in the Women's Employment Study (Discussion Paper No. 1315-06). Madison, WI: Institute for Research on Poverty.

Henrici, J. (Ed.). (2006). Doing without: Women and work after welfare reform. Tucson: University of Arizona Press.

Huffman, S. K., \& Jensen, H. H. (2008). Food assistance programs and outcomes in the context of welfare reform. Social Science Quarterly, 89, 95-115.

Lichter, D. T., \& Jayakody, R. (2002). Welfare reform: How do we measure success? Annual Review of Sociology, 28, 117-141.

Mabli, J., Cohen, R., Potter, F., \& Zhao, Z. (2010). Hunger in America 2010: National report prepared for Feeding America (Tables 5.8.3.1, 5.8.3.2). Princeton, NJ: Mathematica Policy Research.

Mettler, S., \& Milstein, A. (2007). American political development from citizens' perspective: Tracking federal government's presence in individual lives over time (Table 1). Studies in American Political Development, 21, 110-130.

Meyer, B. D. (2009). The effects of the EITC and recent reforms (Working Paper 09.10). Chicago: Harris School of Public Policy Studies.

Michalopoulos, C. (2004). What works best for whom: Effects of welfare and work policies by subgroup. New York: MDRC.

Morgen, S., Acker, J., \& Weigt, J. (2010). Stretched thin: Poor families, welfare work, and welfare reform. Ithaca, NY: Cornell University Press.

Morgen, S., \& Maskovsky, J. (2003). The anthropology of welfare "reform": New perspectives on U.S. urban poverty in the post-welfare era. Annual Review of Anthropology, 32, 315-338.

Moynihan, D. P. (1996, July 18). Personal Responsibility, Work Opportunity, and Medicaid Restructuring Act of 1996, 104th Cong., 142 Cong. Rec. 8070-8076.

Neubeck, K. J. (2006). When welfare disappears: The case for economic human rights. New York: Routledge.

Patient Protection and Affordable Care Act, P.L. 111-148, \ 3502, 124 Stat. 119, 124 (2010).

Personal Responsibility and Work Opportunity Reconciliation Act, P.L. 104-193, 110 Stat. 2105 (1996).

Pierson, P. (2004). Politics in time: History, institutions, and social analysis. Princeton, NJ: Princeton University Press.

Pierson, P. (2007). The costs of marginalization: Qualitative methods in the study of American politics. Comparative Political Studies, 40, 145-169.

Piven, F. F. (2006). The politics of retrenchment: The U.S. case. In M. Moran, M. Rein, \& R. E. Goodin
(Eds.), The Oxford handbook of public policy (pp. 858-873). Oxford, England: Oxford University Press. Piven, F. F., \& Cloward, R. A. (1971). Regulating the poor: The functions of public welfare. New York: Vintage.

Ratcliffe, C., \& McKernan, S. (2010). How much does $S N A P$ reduce food insecurity? Washington, DC: Urban Institute.

Rosenberg, L., Derr, M., Pavetti, L., Asheer, S., Angus, M. H., Sattar, S., et al. (2008). A study of states' TANF diversion programs. Princeton, NJ: Mathematica Policy Research.

Seccombe, K. (2010). So you think I drive a Cadillac? Welfare recipients' perspectives on the system and its reform (3rd ed.). New York: Prentice Hall.

Sherman, A. (2009). Methodological appendix: Safety net effective at fighting poverty but has weakened for the very poorest. Washington, DC: Center on Budget \& Policy Priorities.

Social Security Act of 1935, P.L. 74-271, 49 Stat. 620

Soss, J., Schram, S. F., Vartanian, T. P., \& O’Brien, E. (2001). Setting the terms of relief: Explaining state policy choices in the devolution revolution. American Journal of Political Science, 45, 378-395.

Urban Institute. (1997-2008). Welfare rules database. Retrieved from http://anfdata.urban.org/wrd/ WRDWelcome.CFM

U.S. Department of Agriculture. (1995-2008). Household food security in the United States. Retrieved from http:// www.ers.usda.gov/publications.aspx? Topic $=1681$

U.S. Department of Health and Human Services. (1997). Indicators of welfare dependence. Retrieved from http:// aspe.hhs.gov/hsp/indicators-rtc/index.shtml

U.S. Department of Housing and Urban Development. (2007-2010). Annual homeless assessment reports. Retrieved from http://www.huduser.org/portal/ publications/povsoc/ahar_4.html

U.S. House of Representatives. (1996). Background material and data on the programs within the jurisdiction of the Committee on Ways and Means [Green Book]. Washington, DC: Author.

U.S. House of Representatives. (2006). Background material and data on the programs within the jurisdiction of the Committee on Ways and Means [Green Book]. Washington, DC: Author.

U.S. House of Representatives. (2008). Background material and data on the programs within the jurisdiction of the Committee on Ways and Means [Green Book] (Tables 7-21, 7-22). Washington, DC: Author.

Watkins-Hayes, C. (2009). The new welfare bureaucrats: Entanglements of race, class, and policy reform. Chicago: University of Chicago Press.

Wedeen, L. (2010). Reflections on ethnographic work in political science. Annual Review of Political Science, 15, 255-272.

Zedlewski, S., \& Golden, O. (2010). Next steps for Temporary Assistance for Needy Families (Brief 11). Washington, DC: Urban Institute.

Ziliak, J. P. (Ed.). (2009). Welfare reform and its long-term consequences for America's poor. New York: Cambridge University Press.

Stephen Pimpare, PhD, is adjunct associate professor, Columbia University School of Social Work and Silberman School of Social Work at Hunter College; e-mail: stephenpimpare@ yahoo.com.

Original manuscript received August 3, 2011

Final revision received October 18, 2011

Accepted January 3, 2012

Advance Access Publication December 12, 2012 